Georgia State University

ScholarWorks @ Georgia State University

\title{
In the Beginning There Was Death: Spiritual Desolation and the Search for Self in Jamaica Kincaid's "Autobiography of My Mother"
}

\author{
Elizabeth J. West \\ Georgia State University, ewest@gsu.edu
}

Follow this and additional works at: https://scholarworks.gsu.edu/english_facpub

Part of the English Language and Literature Commons

\section{Recommended Citation}

West, E. (2003). In the beginning there was death: Spiritual desolation and the search for self in Jamaica Kincaid's "Autobiography of My Mother." South Central Review, 20(2/4), 2-23.

This Book Review is brought to you for free and open access by the Department of English at ScholarWorks @ Georgia State University. It has been accepted for inclusion in English Faculty Publications by an authorized administrator of ScholarWorks @ Georgia State University. For more information, please contact scholarworks@gsu.edu. 


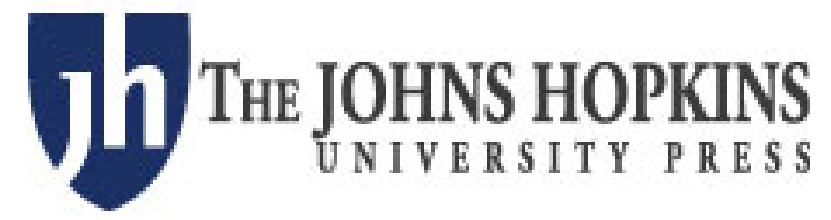

\section{The South Central Modern Language Association}

In the Beginning There Was Death: Spiritual Desolation and the Search for Self in Jamaica Kincaid's "Autobiography of My Mother"

Author(s): Elizabeth J. West

Source: South Central Review, Vol. 20, No. 2/4 (Summer - Winter, 2003), pp. 2-23

Published by: The Johns Hopkins University Press on behalf of The South Central Modern Language

Association

Stable URL: http://www.jstor.org/stable/3189783

Accessed: 05/12/2013 15:00

Your use of the JSTOR archive indicates your acceptance of the Terms \& Conditions of Use, available at

http://www.jstor.org/page/info/about/policies/terms.jsp

JSTOR is a not-for-profit service that helps scholars, researchers, and students discover, use, and build upon a wide range of content in a trusted digital archive. We use information technology and tools to increase productivity and facilitate new forms of scholarship. For more information about JSTOR, please contact support@jstor.org. 


\section{In the Beginning There Was Death: Spiritual Desolation and the Search for Self in Jamaica Kincaid's Autobiography of My Mother}

Elizabeth J. West

Georgia State University

Jamaica Kincaid's novels have invited considerable commentary on the mother-daughter relationships of her fictional heroines. While the undercurrent critique of white domination in Annie John (1978) and the inimical vision of British imperialism in Lucy (1990) have gone unacknowledged by many scholars, the unrelenting harshness of The Autobiography of My Mother (1996) does not allow for such critical neglect. ${ }^{1}$ For Kincaid's fictional female trilogy_Annie, Lucy and Xuela-"alienation from the mother becomes a metaphor for ... alienation from an island culture that has been completely dominated by the imperialist power of England." 2 With its focus on Christianity's place in the lives of those dispossessed by western exploitation, The Autobiography of My Mother is more explicit in its indictment of imperialism. Through the enigmatic existential protagonist, Xuela, Kincaid traces the resultant spiritual wasteland that is the legacy for this post-Colonial victim who rejects the master's God, but whose disconnectedness with her ancestral past leaves her unable to reclaim the gods of her past. The Autobiography of My Mother is not Kincaid's first fictional contemplation of identity and colonialism. ${ }^{3}$ In Annie John, the protagonist suffers a mental breakdown that "can also be read as a breakdown with the past, with tradition." 4 Like Xuela, Annie finds herself reconciling her African-based inheritance with a contrasting but dominant western presence. When Annie suffers a mental breakdown, she is restored to health through the community of women and their ties to African spiritual practices. ${ }^{5}$ In contrast to Annie's

(c) South Central Review 20.2-4 (Summer - Winter 2003): 2-23. 
narrative of identity, Xuela's narrative will neither confirm her identity nor free her from a despairing past. Xuela will find no community to provide her a meaningful sense of place and selfthe self she ultimately constructs is defined by loss and isolation.

Social paradigms of race and gender complicate Xuela's search for self, but it is her concurrent spiritual struggle that ultimately shapes the empty self that emerges. She finds that Christianity offers no personal solace, and that for Blacks collectively Christianity offers little more than unfulfilled promises of solace and deliverance. The vacuity of the Christian message cannot be answered by looking back to the spiritual legacy of the ancestors, for the African-based spirituality that had once connected African-descent people has been lost. For Xuela, this loss translates to personal loss; in particular, it precipitates her inability to construct a meaningful identity. The paradox of Xuela's identity is articulated by Xuela herself. She understands and accepts that she was born into a legacy of defeat, and her answer to this fate is to construct a self that is insulated and self-serving:

I am of the vanquished, I am of the defeated ... for me the future must remain capable of casting a light on the past such that in my defeat lies the beginning of my great revenge. My impulse is to the good, my good is to serve myself. I am not a people, I am not a nation. I only wish from time to time to make my actions of a people, to make my actions be the actions of a nation. ${ }^{6}$

She presumes to see life in its veritable emptiness-a vision that escapes the racial victor (Whites) as well as the racially vanquished (Blacks). The power of her vision, however, only offers a life filled with a lingering emptiness, for she sees death as the ultimate power over life. From infancy, death will signal pivotal moments in her life: "My mother died at the moment I was born . . . at my beginning was this woman whose face I had never seen, but at my end was nothing, no one between me and the black room of the world" (AOMM 3). This bleakness, recounted in the first lines of the novel, will resonate throughout. While the novel exemplifies Kincaid's masterful manipulation of language, it offers a despairing and gloomy message. From beginning to end, the narrator maintains this desolate vision, 
and she will conclude her narrative with the despair of the beginning, confirming once again that "[d]eath is the only reality, for it is the only certainty, inevitable to all things" (AOMM, 228).

What then does a novel like Kincaid's Autobiography of My Mother offer its readers? What can we make of it as a black novel when we consider that it is not controlled by "master discourses of race?" 7 The despair of Kincaid's protagonist is not entirely connected to an explicit or sustained racial theme, which perhaps leaves readers frustrated. While Kincaid calls attention to the protagonist's recognition of her racialized self, the novel does not position race as the controlling discourse. Xuela's search for self is thwarted in greater part by the spiritual void in her life than by a prevailing struggle with racial issues. Her moments of racial reflectiveness do not prompt her to action that alters the course of the narrative. Instead, issues of personal/ subjective desire emerge and influence her choices.

Claudia Tate argues that novels with themes that are "external to [the] racial/social argument" of the text result in an "enigmatic surplus [that] disrupts the novel's conscious plot around racial/social protest or affirmation." 8 Enlisting W. E. B. DuBois's not-so-highly praised novel, Dark Princess, Tate suggests that "the novel's finale engenders our wonder and amazement but fails to evoke our empathy, compassion, or identification . . . offer[ing] us no site for entry."9 The Autobiography of My Mother exemplifies Tate's analogy of black authored texts with surplus desire that "generate meaning in the novel that is external to its racial/social argument."10 Xuela is less a victim of the ills of racism than a victim of a sustained longing resulting from a trauma experienced at birth. This character, who for the most part remains unnamed in a narrative that she controls, longs for what she will never havea mother. That longing will translate into a spiritual longing that will also go unanswered. Her elusive father, who is her only living connection to her mother, will deny Xuela both a tie to himself and to her mother. Having no mother and no functional father, Kincaid's enigmatic heroine has no link to the past and no road to the future. Her mythical mother, had she lived, may have proven a link to the ancestral spirits. Acknowledging only the gods of the victors, however, Xuela's father does not give merit to an African ancestral connection. 
The Autobiography of My Mother maintains a critique on racism; in particular, the narrator addresses issues of white privilege and black despair. Early in the novel Xuela positions herself as the racial other. She recalls speaking first in the language of the oppressor: "That the first words I said were in the language of a people I would never like or love is now a mystery to me: everything in my life, good or bad, to which I am inextricably bound is a source of pain" (AOMM 7). Although Xuela speaks the language of the conqueror before uttering her native tongue, her instinctive rejection of things British surfaces early. As a toddler she accidentally breaks a plate belonging to her surrogate mother, Ma Eunice. The plate, painted with "a picture of the English countryside idealized," and labeled "HEAVEN," was a treasured icon (AOMM 9). Xuela realizes the importance of the plate to Ma Eunice; however, she is unable to apologize. She instinctively rejects the message of reverence for the oppressor suggested in the image painted on the plate.

While Xuela repeatedly identifies the British as those who have gained privilege by their abuse and exploitation of racial others, she fails to mediate her personal narrative into this theme. She is black, but hers is a complicated identity. Her mother was "of the Carib people" who had been exterminated by the British and were disliked by those of African descent. Her father was the product of a union between a Scots-man and a woman of African descent. Given popular constructions of race, Xuela is identified as black. However, Xuela sees herself as both a physical and spiritual hybrid. She will identify herself as having come from many but belonging to none. She discloses the complexity of racial realities and racial constructions but does not demonstrate that her own story is significantly influenced by this social paradox. The novel ends with a racial discourse and a discourse of personal desire that have not been merged into a unified narrative.

Xuela's personal longing begins at the moment of her birth with the traumatic loss of her mother. From early childhood she seeks her mother, though she knows that it is a futile search: "I missed the face I had never seen; I looked over my shoulder to see if someone was coming, as if I were expecting someone to come ... I was just looking for that face, the face I would never see, even if I lived forever" (AOMM 5). She experiences 
apparitions in which her mother appears, but she is always denied the vision of her mother's face: "She came down the ladder again and again, over and over, just her heels and the hem of her white dress visible; down, down, over and over" (AOMM 31). By the age of seven Xuela has become quite familiar with this vision, and she accepts that she will never look upon her mother's face. But this acceptance represents a resignation-not a resolution. Hence, the narrative continues as a contemplation of loss and a desire for a mother. The memory of the loss will remain, and in the closing moments of the text the protagonist will again remind readers that hers is a narrative of maternal disconnectedness: "That attachment, physical and spiritual, that confusion of who is who, flesh and flesh, which was absent between my mother and her mother was also absent between my mother and myself, for she died at the moment I was born, and though I can sensibly say to myself such a thing cannot be helped-for who can help dying - again how can any child understand such a thing, so profound as abandonment? I have refused to bear any children" (AOMM 199).

As the narrative unfolds the reader learns that this loss represents a legacy of loss: in infancy her mother was abandoned and left at the gates of a convent, and her father was abandoned in his youth by his father. Her father will not physically abandon her; however, he becomes himself a symbol of unfulfilled desire. She longs for a connectedness to her father who will never allow her entry into his inner world or share with her his memory of her mother. This father, who shortly after her mother's death delivers Xuela to the door of his laundry woman, will prove the living conscious source of her self-consumed existence:

When my mother died, leaving me a small child vulnerable to all the world, my father took me and placed me in the care of the same woman he paid to wash his clothes. It is possible that he emphasized to her the difference between the two bundles: one was his child, not his only child in the world but the only child he had with the only woman he had married so far; the other was his soiled clothes. He would have handled one more gently than the other, he would have given more careful instructions for the care of one over the other, he would 
have expected better care for one than the other, but which one I do not know, because he was a very vain man, his appearance was very important to him. That I was a burden to him, I know; that his soiled clothes were a burden to him, I know; that he did not know how to take care of me by himself, or how to clean his own clothes himself, I know. (AOMM 4)

Throughout the narrative, the vision of her father triggers feelings of overwhelming despair and disillusionment. She will, however, occasionally contemplate the possibility of goodness in her father, but the distance between father and daughter will remain. Xuela's only admirable memory of her father is his handwriting which she remembers as "such a beautiful thing to behold. It covered the page with strong curves and strong dashes and strong slashes" (AOMM 95). Ironically, she is in awe of his handwriting, but she cannot read it. Her inability to read her father's writing exemplifies her inability to read her fathereven though he, like his handwriting, seems bigger than life. His world is off limits to her; she cannot read his handwriting just as she cannot read his face or his actions.

Having no mother and no functional father, Xuela faces an unconquerable void. She understands that she will never possess the self knowledge, connectedness, or inheritance that parents impart to their children: "Observing any human being from infancy, seeing someone come into existence, like a new flower in a bud ... all this is something so wonderful to behold; the pleasure for the observer, the beholder, is an invisible current between the two, observed and observer, beheld and beholder, and I believe that no life is complete, no life is really whole, without this invisible current, which is in many ways a definition of love. No one observed and beheld me, I observed and beheld myself" (AOMM 56). Xuela, then, learns of self through a self-reflexive process-she cannot gaze into the eyes of a parent and find her image. She will, like her father, create herself, and she will, ironically, create a self that mirrors the father she so despises. She has inherited his soul even though he has disinherited her materially. He denies her the spiritual inheritance that she desires, and she does not require his material means, for she has learned from him the ruthless road to possessing wealth. Like her father, she will come to weigh the 
interest of self as primary. She acknowledges and is empowered by her self-interest: "My own face was a comfort to me, my own body was a comfort to me, and no matter how swept away I would become by anyone or anything, in the end I allowed nothing to replace my own being in my own mind" (AOMM 100). And just as her father had chosen a spouse he did not love, she too would forego love and choose instead a spouse who would answer her desire for material gain.

At its core, the complex estrangement between Xuela and her father may be an outgrowth of the effects of racism. Certainly, her father has been influenced by a society in which a white father can so easily abandon his family of color. Certainly, Xuela has been influenced by the question of identity that is imposed on one who is a hybrid of races, but in her self-absorbed narrative, race is de-centered as the master discourse. Xuela struggles with issues of personal loss and personal desire that cannot be answered by an emerging racial consciousness. She marries a white man, but she finds no community or kinship with Whites. While she is looked upon as black, she forms no substantive connections with Blacks. There is no opportunity for kinship with the Carib people of whom her mother was a descendant, for they have long been killed off by conquering Whites. Xuela represents the existential protagonist who seats herself at the center of her world, constructing codes of ethics and morality that originate in her own self-conceived and selfvalidated paradigms. She does not appropriate the discourse of spiritual enlightenment often found in the bildungsroman. While the novel recounts Xuela's coming of age, it disrupts this literary convention by not only negating Christianity as the source of the protagonist's transformation, but by further dismissing spirituality as a source of self-empowerment. In the post-Colonial world of this displaced heroine, no spiritual solace is found: Christianity is innately corrupt and the connection between Africans and their pre-Colonial spirituality has been severed. In the absence of spiritual bonds, race is not sufficient to tie Xuela to Blacks in her community. The result is a spiritual wasteland that confirms her alienation and loss.

Through her inversions of Christian myths and ideals, Xuela unveils Christianity's failure. Her own beginning overturns the biblical creation story that marks the beginning of life as a 
generative moment. For Xuela the beginning is a paradox marked not by life, but rather by death and loss: the beginning for Xuela marks death for her mother. In contrast to the creation story that promises life and hope, Xuela's narrative suggests that the beginning is only a cruel paradox in which life emerges out of death, and life itself is only a journey to death. Instead of the gift of Eden that God awards the first humans, Xuela finds life a "false paradise ... full of life, full of death, able to sustain the one, inevitably to claim the other" (AOMM 32). Born out of this paradox, Xuela repeatedly subverts the anticipated spiritual revelation commonly appropriated in coming-of-age narratives. She experiences no moment of spiritual revelation that ties her to community, leads her to identity, or answers her personal yearnings.

The paradoxical gaining of life through the death of another will prove a recurrent trope in The Autobiography of My Mother. The narrator reminds the reader repeatedly that her birth occurred with the concurrent death of her mother. In a chorallike chant near the novel's end she reflects on her mother's life, confirming and reconfirming one fact about her mother: "she died at the moment I was born" (AOMM 198). Her own emergence into life through the death of her mother compels Xuela to deny the emergence of life through her own body. With god-like authority, she denies life to those who might threaten her own. Her first abortion awakened her to the power she possessed to will out unwanted life. She remembers the subsequent revelation of self that was born out of this destructive act: "I was a new person then, I knew things I had not known before, I knew things that you can know only if you have been through what I had just been through. I had carried my own life in my own hands" (AOMM 83). Through the near death experience brought on by the physical trauma of her abortion, Xuela is born again. In an unconscious state she sets off on a mystical journey in which the imagery of her resurrection is juxtaposed with that of the risen Christ. On a journey that begins out of a sacrilegious act, Xuela beholds images revered by Christians: "At Massacre the entire Church of St. Paul and St. Anne was wrapped in purple and black cloth as if it were Good Friday" (AOMM 87). Good Friday is the holiday celebrated by Christians in remembrance of God's promise of eternal life. Christians 
remember it as the day of Christ's resurrection, and the color purple signifies the eminence of God's chosen son. In contrast to the risen Christ, the chosen son, who, resurrected from the dead, promises eternal life to humankind, Xuela, the dispossessed daughter, is resurrected from the dead through her denial of life to another. Following her first abortion Xuela returns to the home of Lise, the woman who has befriended her. Here, with Lise and her husband, who fathered the life that Xuela has expelled, the novel's inversion of Christian iconography is once again highlighted. Xuela recalls that they stood in a "little triangle, a trinity, not made in heaven, not made in hell, a wordless trinity" (AOMM 93). Just as the image of the holy trinity-God the father, Jesus the son, and the holy spiritremains a paradox in Christian theology, the image of Xuela, Lise LaBatte, and Jacques LaBatte standing in a kind of trinity is also a paradox. Unlike the holy trinity that originates out of God's gift of life to humankind, theirs is a union conceived in the unholy act of adultery and confirmed with the taking of life.

The loss of life will mark two other paradoxical moments of human connectedness for Xuela. While she insists that her father's children are not her sister and brother, she comes to feel a familial bond with them through death experiences. With the death of her brother, Xuela is able to regard him as a sibling: "My brother died. In death he became my brother" (AOMM 110), she explains. Similarly, her momentary connectedness to her sister occurs when they share a death experience. Xuela and her sister have maintained a mutual disregard that goes uninterrupted with the exception of one episode:

\begin{abstract}
She became my sister when shortly after she was expelled from school she found herself with child and I helped her rid herself of this condition ... I hid her in my small room behind the kitchen ... I made her strong potions of teas. When the child inside her still refused to come out, I put my hand up inside her womb and forcibly removed it. (AOMM 114)
\end{abstract}

When this crisis is over Xuela's sister offers her no gratitude for her services. In fact, while Xuela's deed offers her a moment of connectedness to her sister, it cements her sister's dislike for her: "I never became her sister; she never took me into her 
confidence, she never thanked me; in fact, the powerful clasp in which she could see I held my own life only led to more suspicion and misunderstanding" (AOMM 115). With her father, Xuela will likewise know no familial connectedness, but his death precipitates a moment of renewed life for her. She remembers her father's death as a kind of redemption:

I had been living at the end of the world for my whole life; it had been so when I was born, for my mother had died when I was born. But now, with my father dead, I was living at the brink of eternity, it was as if this quality of my life was suddenly raised from its usual self, embossed with its old meaning. (AOMM 213)

Death is regenerative for Xuela; it marks the beginning of her life, it affords her the few moments of familial bonding that she experiences, and it endows her with renewed enlightenment and empowerment. As the source of Xuela's empowerment and regeneration, death, the omnipresent power, signifies the novel's subversion of Christianity's greatest promise. Whereas in Christian myth God is the power that rules over death and grants humankind eternal life, Xuela's ideology holds death as the ultimate authority. The novel's allusion to the biblical figure Lazarus exemplifies this inversion. The appropriation of this well-known figure negates the Christian belief in God's power over death and the redemption of the poor in the hereafter. In John 11:1-44 the story is told of Jesus raising Lazarus from the grave. Dead for four days, Lazarus is brought back to life to demonstrate God's power of resurrection. A biblical account of another Lazarus contrasts the life of a symbolic rich man with that of the beggar, Lazarus. Lazarus, though poor and dejected in the carnal world, triumphs in the afterlife while the rich man is condemned to hell (Luke 16:19-31). In her narrative Xuela will recall two encounters with a poor man named Lazarus; however, this Lazarus is not resurrected from the dead, and he does not come to know the promise of heavenly recompense. On the contrary, Xuela's Lazarus is the embodiment of death, of the hopelessness of life, and his life suggests that there is no just reward for the poor-in this life or another.

In addition to being a poor man, Xuela's Lazarus is a gravedigger-that image of the doorkeeper to the gates of death. 
Though he may have been given the name Lazarus as an act of faith, this Lazarus cannot escape that eminent and omnipotent power-death. Xuela detects the contradiction between what his name signifies and what his fate will be:

his name would have been given to him in a moment of innocent hope; his mother would have thought that such a name, rich and powerful as it was with divine second chance, would somehow protect him from the living death that was his actual life; but it had been of no use, he was born the Dead and he would die the Dead. (AOMM 140)

This Lazarus will be exploited by Xuela's father, a rich man who, unlike the rich man in the biblical tale, suffers no consequences for his acts. And this Lazarus will not realize redemption in the afterlife. While Xuela attempts to intercede on Lazarus's behalf when he comes to her father in need, she does not find the success of the biblical Mary and Margaret who are able to employ Jesus to come to the aid of Lazarus. In fact, Xuela will herself become the object of her father's scorn because of her plea for Lazarus. He angrily shows Xuela the nails that he has told Lazarus he does not have. Refusing Lazarus the nails he needs to build a roof, Xuela's father denies him fundamental protection. Lazarus has no physical home and he knows no spiritual refuge; his name symbolizes the Christian promise of redemption and salvation, but he is the embodiment of human despair and hopelessness.

The novel's negation of Christianity's power and sacredness is also revealed with Xuela's allusion to the biblical book, Romans. As a young child Xuela writes secret letters venting her feelings of victimization suffered at the hand of her teacher. A boy named Roman uncovers her letters and turns them in:

My letters did not remain a secret. A boy named Roman had seen me putting them in their secret place, and behind my back, he removed them. He had no empathy, no pity; any instinct to protect the weak had been destroyed in him. He took my letters to our teacher. (AOMM 20)

The boy Roman, evil and cunning, clearly contrasts the image of sacredness associated with the biblical book, Romans. The 
inversion of Christian iconography is further evident in the contrasting nature of Xuela's secular letters and Paul's spiritual letters. Paul's letters have not been authored in the interest of self but for the greater cause of spreading the Christian message. Though Xuela addresses these letters to her father, she has no intention of sending them. She has authored these letters to provide herself solace and vindication. As author, Xuela stands in contrast to Paul, but her ethnic hybridity is reminiscent of Paul's cross cultural identity. Though a Christian apostle, Paul is a Jew by birth; while a Jew, he is a Roman citizen. ${ }^{11}$ Xuela embodies a similar hybrid of cultures: though she is assumed to be black, her mother is a descendant of the Carib people, and her father is of mixed African and Scottish blood. With his acceptance of Christ's message that all are one under God, Paul successfully negotiates his Jewishness and his belief in Christianity. Xuela, however, is a splintered self who finds no spiritual message that enables her to merge her multiple selves into a unity of self.

Undermining a tradition of Christian myths and claims, The Autobiography of My Mother suggests the failure of Christianity in the lives of the conquered Africans. Kincaid's protagonist recognizes that adaptation to Christianity has not brought Africans the prosperity that it brought the conquering Whites. In her teacher, the young Xuela witnesses the discord that Christianity cultivates. A woman of African ancestry educated by Methodist missionaries, Xuela's teacher had learned to view her ancestry with shame, and it was a sentiment widespread among this community of African descendants:

\begin{abstract}
My teacher ... was of the African people, that I could see, and she found in this a source of humiliation and selfloathing, and she wore despair like an article of clothing, like a mantle, or a staff on which she leaned constantly, a birthright which she would pass on to us. She did not love us; we did not love her; we did not love one another, not then, not ever. (AOMM 15)
\end{abstract}

For her teacher and for Africans at large, colonialism and Christianity had displaced self love and ancestral ties. Christianity had been the tool of exploitation employed by the conquerors and later by the conquered themselves. In Xuela's 
own father we see the parasitic nature of Christianity personified. A self-made man, her father came into his wealth by exploiting those in his community. The more respected he became, the more corrupt and the more religious he became: "My father had become a Methodist, he attended church every Sunday; he taught Sunday school. The more he robbed, the more money he had, the more he went to church; it is not an unheardof linking" (AOMM 40).

Church, then, is the institution that confirms the defeat of the conquered. Xuela observes Blacks as they submit themselves each Sunday to this self-defeating ritual:

This activity—going to church, coming from church-had about it an atmosphere of a decree. It also signified defeat yet again, for what would the outcome have been of all the lives of the conquered if they had not come to believe in the gods of the people who had conquered them? (AOMM 133)

Xuela contends that the conquered African people, dispossessed of their own spiritual heritage and denied the Christian promise of redemption, are left to despair. She recalls the history of the church in the small town of Roseau, a history that symbolizes the spiritual dispossession of colonized Africans:

But this church, typical of its time and place in every way, was built, inch by inch, by enslaved people, and many of the people who were slaves died while building this church, and their masters then had them buried in such a way that when the Day of Judgment came and all the dead were risen, the enslaved faces would not be turned toward the eternal light of heaven but toward the eternal darkness of hell. (AOMM 133)

Stripped of their own legacy and denied a place in Anglo religious tradition, these Africans lack cultural identity and strength, and as in the case of Xuela's teacher, they are filled with self-loathing.

The conquered do not entirely submit. Some hold on to ancestral ways. Ultimately, however, they find that ancestral myths collapse under the overreaching influence of Christianity. 
This subjugation of African myth to western spiritual hegemony is illustrated early in the novel with Xuela's account of her young classmate who disappeared after being called into the river by an apparition of a woman. Xuela recalls observing this naked woman who in their eyes was beautiful. Hers was a beauty that they understood and were drawn to because she resembled them: ". . . she was dark brown in skin, her hair was black and shiny and twisted into small coils all around her head. Her face was like a moon, a soft, brown, glistening moon" (AOMM 35). Mesmerized and unable to move away, they watched her. Though she embodied a beauty and a familiarity that attracted them, they were nevertheless uneasy. One boy in the group, swayed to come nearer, swam farther and farther in his attempt to reach her. He finally drowned from exhaustion, and he and the apparition disappeared. The children who witnessed this mystical event are made to doubt what they have seen. The story will live on as a folkloric tale bearing little resemblance to the truth of their experience. But as an adult looking back, Xuela understands why those in her community, even the children who had witnessed it firsthand, could not accept this event as real:

Everything about us is held in doubt and we the defeated define all that is unreal, all that is not human, all that is without love, all that is without mercy. Our experience cannot be interpreted by us; we do not know the truth of it. Our God was not the correct one, our understanding of heaven and hell was not a respectable one. Belief in that apparition of a naked woman with outstretched arms beckoning a small boy to his death was the belief of the illegitimate, the poor, the low. I believed in that apparition then and I believe in it now. (AOMM 37-38)

Those Blacks who attempt to maintain ancestral practices meet with failure in this community that finds little or no value in African-based practices and ideals. Such is the case with Madame La Batte's spell gone wrong. While a young woman, she is unable to secure a marriage proposal from Jacques LaBatte who has refused other women wanting to marry him. She calls on mystical practices to lure him, but the spell quickly 
wears off and Monsieur LaBatte is no longer under her command. In fact, she becomes the victim as this relationship drains her of life and will. Similarly, when Xuela's stepmother calls on the god of her ancestors to save her dying son, she witnesses the powerlessness of this resource. Xuela recalls the paradoxical image of the boy's mother praying to the ancestral god while his father calls on the Christian god:

Inside that yellow house with the brown windows, my father's son was lying on a bed of clean rags that was on the floor. They were special rags; they had been perfumed with oils rendered from things vegetable and animal. It was to protect him from evil spirits. He was on the floor so that the spirits could not get to him from underneath. His mother believed in obeah. His father held the beliefs of the people who had subjugated him. (AOMM 108)

In the end both gods fail the young boy. His death symbolizes the spiritual death of this community of displaced Africans who share no vital ties of ancestry. Like this mother and father whose beliefs are at odds, the community too is at odds. They are a house divided between the ways of the conqueror and the ways of the ancestors. These traditions cannot coexist, and the result for this community is much like that for the frail boy who could not survive at the fringes of two disparate worlds.

Refusing to become one of the powerless, Xuela serves no god, but rather raises herself to godhood. She arrives at this state of self-proclaimed divinity through experiences that cultivate in her a desire for power. This is evident early in her childhood when shortly after Ma Rainey has reprimanded her for breaking her treasured plate, Xuela takes three young turtles and keeps them captive. Feeling helpless and victimized, Xuela wishes to emulate the power that Ma Rainey has exercised with her. She chooses three turtles as her victims, capturing them so that they completely depend on her. Punishing the turtles for withdrawing into their shells, she seals the holes from which they refuse to emerge. When she remembers them some days later, she returns to find them dead. She does not recall this event with sorrow or remorse, 
but with a godlike indifference. She had wished something of the turtles, they had denied her, and she had killed them in an attempt to gain their obedience. This incident, in part, symbolizes her struggle with Ma Rainey, who responds to Xuela's insolence by exercising her power to punish her, to make her suffer. Xuela, in turn, discovers her own power through her experiment with the turtles. But she has surpassed Ma Rainey, for she has exercised the power to take life.

Xuela's association of power with death evolves into a more conscious philosophy as she matures. The incident between Xuela and her teacher reveals this emerging consciousness. In a moment that echoes the powerlessness Xuela felt at the hands of Ma Rainey, Xuela again finds solace in knowing her power to take life. When her teacher reads her letter and verbally reprimands her before her classmates, Xuela becomes fixated with a spider on the wall. She remembers her overwhelming desire to destroy this spider: ". . . I wanted to reach out and crush it with the bare palm of my hand, because I wondered if it was the same kind of spider or a relative of the spider that had sucked saliva from the corner of my mouth the night before as I lay sleeping, leaving three small, painful bites" (AOMM 21). Xuela does not kill the spider, but her desire to kill demonstrates her connection of death and power. When the confrontation with her teacher leads to Xuela's removal from the school, she realizes that this incident has ultimately resulted in the fulfillment of her desire to leave. If, as Xuela suspects, she had saved her own life by her actions, it had been inadvertently; however, shortly after arriving at the house of her father and his new wife she will be required to deliberately orchestrate a plan to save herself from death. Instinctively knowing that the necklace her stepmother has given her as a gift is in fact a death object, Xuela presents this necklace as a gift to her stepmother's favorite dog, who soon afterward dies. At this point Xuela has transformed her power to the deliberate act of taking life. She killed the turtles accidentally, and she only imagined killing the female spider; however, when she places the necklace on the dog, knowing that it is an instrument of death, she has, for the first time, deliberately taken life. 
Xuela's indifference at the taking of life will be brought to fruition with her refusal to allow life to come from her body, and her subsequent self-inflicted abortions exemplify her determination to control life and death.

Recognizing and exercising her power to determine the course of her life, Xuela relishes in her "self." This celebration of the self leads her to an ongoing practice of self-sensual/sexual gratification. Though she seeks intimacy with men, she regularly pleases herself, and she holds nothing in life before herself. Xuela becomes for Xuela the greatest presence in lifeno greater source of knowledge, of pleasure, or power can she find. She is the god in her world, and her own face becomes the graven image that reifies her authority:

When I could not see my face, I could feel that I had
become hard; I could feel that to love was beyond me,
that I had gained such authority over my own ability to
be that I could cause my own demise with complete
calm. I knew, too, that I could cause the demise of
others with the same complete calm. It was seeing my
own face that comforted me. I began to worship
myself . . . in the end I allowed nothing to replace my
own being in my own mind. (AOMM 99-100)

Xuela revels in her power of self-rule, but ultimately she must recognize and concede to powers greater than herself. Her godlike reach is limited: what she seeks most she will never possess. Reminiscent of the biblical Eve who seeks knowledge that is beyond human capacity, Xuela admits that what she desires most she can never have. She confesses, "to know all is an impossibility, but only such a thing would satisfy me," and at the close of the novel Xuela signals her submission to that authority to whom all must submit-death (AOMM 226-28).

Although Xuela must ultimately submit to death, this does not diminish her compelling role as the seer. She sees Christianity draining the lifeline of Africans, she sees Africans unable to maintain the ways of their ancestors, she sees Africans as a disempowered people, she sees Whites as usurpers, and she asserts her rejection of all these legacies. Xuela will create herself, and this construction of self begins in 
the aftermath of her first abortion. She recounts the dream that revealed the legacy that would define her:

I walked through my inheritance, an island of villages and rivers and mountains and people who began and ended with murder and theft and not very much love. I claimed it in a dream. Exhausted from the agony of expelling from my body a child I could not love and so did not want, I dreamed of all the things that were mine. (AOMM 89)

She is awakened out of this dream by her father whose presence reminds her of the uncertainty and the void in her life. She has claimed the inheritance of the unloved, of the dejected, of the abused. It is fitting, then, that after she comes to know her mother, she will choose the inheritance of her mother. Xuela reconstructs her mother's image and life through what she has been told, and the image that emerges confirms the picture offered at the novel's beginning-her mother will stand again as an icon of death and loss. She imagines that from a young age her orphaned mother had been shaped by the nuns into a "quiet, shy, long-suffering, unquestioning, modest, wishing-to-die-soon person," and that upon first meeting her mother, her father noticed "her sadness, her weakness, her long-lost-ness, the crumbling of ancestral lines, her dejectedness, the false humility that was really defeat" (AOMM 199-200).

Although she has claimed powers of life and death and vision, Xuela becomes one of the dispossessed, the vanquished. And while she has claimed herself godlike, she has no greater knowledge of self than the defeated masses who have become victims of western domination. She finally concedes that life is a paradox, a mystery that remains unknowable. Her choice to retreat to the homeland of her mother signals this defeat, for she has identified her mother as one among the defeated. Her retrospection near the close of the novel suggests that giving the account of her life as an autobiography of her mother reveals her inextricable tie to the world of the defeated:

This account of my life has been an account of my 
mother's life as much as it has been an account of mine, and even so, again it is an account of the life of the children I did not have, as it is their account of me. In me is the voice I never heard, the face I never saw, the being I came from. In me are the voices that should have come out of me, the faces I never allowed to form, the eyes I never allowed to see me. This account is an account of the person I did not allow myself to become. (AOMM 227-28)

Xuela's self-reflection at the end of the narrative is not altogether convincing, and this marks the novel's thematic shortcoming. That this heroine who consciously chooses and relishes in her self-interestedness and isolationism should abruptly shift to a sentimental discourse of unfound love and unfulfilled desire suggests an attempt to endear the protagonist to the reader. Xuela's extreme individualism and her dispassionate tie to others represent the self that she has deliberately constructed. She has privileged the material and corporeal world and claimed herself superior to others because she sees the fruitlessness of all else. Her arrogance and distance may leave readers unmoved by her story, but her spirit of resistance offers readers a site of connection. With her final sentimental lament, however, Xuela has compromised the defiance that has defined her heroic nature. Xuela's inconsistent narrative exemplifies a body of fiction by contemporary black women writers that critic bell hooks suggests is both powerful and problematic. This fiction is significant "in that it clearly names the ways structures of domination, racism, sexism, and class exploitation oppress and make it practically impossible for black women to survive if they do not engage in meaningful resistance on some level," but a prevailing shortcoming in many of these works is that often they "fail to depict any location for the construction of new identities."12 This failing is evidenced in Kincaid's heroine, Xuela. Throughout the narrative, Xuela reiterates the charge that Christianity is a tool of western exploitation; however, it is her belief that the African-descent victims of western domination are unable to meaningfully connect with their preColonial spiritual inheritance that informs her overwhelming 
desolate vision. Her determination to avoid the paralyzing reach of Christianity distinguishes her from the community of victims among whom she lives, but her insight does not lead her to the construction of a healthy self. While readers may applaud Xuela's defiance, they may be less inclined to embrace the empty self that evolves from her superior insight. Xuela is defined by loss, and she is finally consumed by that legacy. She is daring enough to explore the nature of her existence, but she lacks the courage to seek life.

Xuela represents the evolution of a fictional self that Kincaid arrives at through a series of works. Xuela's ontological introspection is foreshadowed in Kincaid's earlier work, At the Bottom of the River (1978), a collection of sketches that explores questions of identity and being. In particular, the speaker's search for knowledge of self in the final vignette is a precursor to Xuela's desire to know the unknowable. Here, however, the speaker accepts the unknowable nature of human existence and accepts that if life is "a violent burst of light, like flint stuck sharply in the dark," then one "must continually strive to exist between the day and the day." 13 Out of the understanding that one cannot know, this speaker, unlike Xuela, is able to construct meaning out of her existence.

In the two novels that followed At the Bottom of the RiverAnnie John (1983) and Lucy (1990)-Kincaid's fictionalized contemplations occur through less abstract characterizations and with clearer musings on the African self in the face of western domination. The protagonists' piercing denunciations of Christianity in these novels symbolize their break with western ideologies. However, for both Annie and Lucy, African spirituality contributes to their construction of an Africanrooted self, and their disengagement from Christianity is ironically exemplified by their self-subscribed allegiance with the Christian personification of evil-Lucifer. ${ }^{14}$ Although Lucy's frequent proclamations of detachment foreshadow Xuela's self-imposed isolation, she, like Annie, maintains a reverence for African-based spirituality. Annie and Lucy are still connected to the world outside themselves-they are connected to others. While they recognize the hypocrisy and untruth veiled in western claims of civility, Annie and Lucy are 
not driven to the spiritual abyss that claims Xuela. Xuela is the nexus as well as the denouement to Kincaid's narrative trilogy. Going beyond Annie and Lucy's rejection of western spirituality, Xuela pronounces African-based spirituality inept and effectively dead. She accepts the resultant void, living at the margin of two worlds, claiming to be part of neither. Disengaged from humanity and any meaningful ideology, Xuela resides in a cosmos of her own. Having left no point of entry for human connection, Xuela's final lament can only echo within the confines of her self-imposed and once celebrated isolationism.

\section{NOTES}

1. In her essay, "Jamaica Kincaid's Writing and the Maternal Colonial Matrix," Laura Niesen de Abruna comments on the inclination of reviewers to emphasize Kincaid's exploration of mother-daughter relationships while ignoring her commentary on colonialism (Caribbean Women Writers: Fiction in English, eds. Mary Condé and Thorunn Lonsdale [New York: St. Martin's Press, 1999], 172-183).

2. Laura Niesen de Abruna, "Jamaica Kincaid's Writing and the Maternal Colonial Matrix,” in Condé and Thorunn, 173.

3. For recent critical discussions on identity and colonialism in Kincaid's works, see Moira Ferguson's Jamaica Kincaid: Where the Land Meets the Body (Charlottesville: University Press of Virginia, 1994); and Diane Simmons's Jamaica Kincaid (New York: Twayne, 1994). See Belinda Edmondson's Making Men: Gender, Literary Authority, and Women's Writing in Caribbean Narrative (Durham: Duke University Press, 1999) for discussion on constructing identity in works by Kincaid and other Caribbean women writers.

4. Wendy Dutton, "Merge and Separate: Jamaica Kincaid's Fiction," World Literature Today 63 (1989): 409.

5. H. Adlai Murdoch's "Serving the Mother Connection: The Representation of Cultural Identity in Jamaica Kincaid's Annie John" (Callaloo 13 [1990]: 325340) and Craig Tapping's "Children and History in the Caribbean Novel: George Lamming's In the Castle of My Skin and Jamaica Kincaid's Annie John (Kunapipi 11 [1989]: 51-59) explore the journey to selfhood in Annie John.

6. Jamaica Kincaid, The Autobiography of My Mother (New York: Farrar Straus Giroux, 1992), 215-16. This text will also be referred to as AOMM.

7. Claudia Tate, Psychoanalysis and Black Novels (New York: Oxford University Press, 1998), 10. Though Autobiography of My Mother is not among the texts considered in Claudia Tate's critical work, Tate's call to consider the implications of black authored novels that lack a race-centered narrative can be applied to a reading of Autobiography of My Mother.

8. Claudia Tate, Psychoanalysis, 13.

9. Claudia Tate, Psychoanalysis, 82.

10. Claudia Tate, Psychoanalysis, 9. 
11. For details of Paul's ancestry see Romans 11:1; Philippines 3:5; Acts 16:37; Acts 22:25-28. Also, Werner Keller's The Bible as History provides an account of Paul's identity (pp. 357-63).

12. bell hooks, Black Looks: Race and Representation (Boston: South End Press, 1992), 50-51.

13. Jamaica Kincaid, At the Bottom of the River (New York: Farrar Straus Giroux, 1983), 73.

14. Jamaica Kincaid, Annie John (New York: Farrar Straus Giroux, 1983), 94-95. Kincaid, Lucy (New York: Farrar Straus Giroux, 1990), 139, 152-53. In both novels the protagonists are described by their mothers as Lucifer. Neither Annie or Lucy find this offensive, perhaps because despite his evil nature, Lucifer stands as the antithesis to Christianity. 